\title{
Corporate Ethics and Corporate Governance: A Critique of the ALI Statement on Corporate Governance Section 2.01(b)
}

Professor Dodd was a prophet crying in the wilderness when he argued in 1932 that corporate directors were trustees for the public's interest as well as for shareholders.' ${ }^{1}$ Since then, however, it appears that all Jerusalein has gone out to confess and be baptized. Today, even a conservative Republican President calls for corporations to increase dramatically their contributions to the arts, human welfare, and the social good. ${ }^{2}$ This growing acceptance of corporate social responsibility is a result of many factors, including: the professionalization of manageinent; ${ }^{3}$ the corporate legitimacy debate of the 1970 's; ${ }^{4}$ and, most recently, the influence of the Japanese corporate style. ${ }^{5}$ As the demand for corporate altruism increases, so does the need for an examination of the legal bases of and limits on corporate ethical behavior.

Corporate ethical conduct, the subject of this Comment, includes more than ethically notivated decisions to inake charitable contributions to philanthropic causes. All business decisions inotivated by corporate officials' ethical inores, rather than their desire to benefit the

1. Dodd, For Whom Are Corporate Managers Trustees?, 45 HARv. L. Rev. 1145, 1160-61 (1932).

2. Teltsch, The Challenge on Donations, N.Y. Times, Nov. 4, 1981, at D1, col. 3.

3. See, e.g., Stone, Corporate Accountability in Law and Morals, in THE JUDEO-Christian VISION AND THE MODERN CORPORATION 267-68 (O. Williams \& J. Houck eds. 1982) [hereinafter cited as Judeo-Christian Vision]; A. Chandler, The Visible Hand: The Managerial Revolution IN AMerican Business 464-68 (1977); Epstein, Societal, Managerial, and Legal Per. spectives on Corporate Social Responsibility-Product and Process, 30 Hastings L.J. 1287, 1298 (1979). It is difficult to tell how much of this rhetoric is simply public relations posturing (i.e., profit-maximizing denials of profit nraximizing), see, e.g., Manne, The Myth of Corporate Responsibility-Or-Will the Real Ralph Nader Please Stand Up?, 26 Bus. LAw. 533, 536 (1970); McClaughry, Milton Friedman Responds: A Business \& Socicty Review Interview, 1 Bus. \& Soc'Y REV. 5,8 (1972), and how much is a justification for self-interested spending to resist takeovers. Small, The Evolving Role of the Director in Corporate Govcrnance, 30 HASTINGs L.J. 1353, 1362 (1979).

4. The legitimacy debate was stimulated by J. HuRST, THE LEGITIMACY OF THE Business CORPORATION IN THE LAW OF THE UNITEd StaTes, 1780-1970 (1970). See also Epstein, supra note 3, at 1291-95; Epstein, The Historical Enigma of Corporate Legitimacy, 60 CALIF. L. REv. 1701 (1972). Cf. Werner, Corporation Law in Search of its Future, 81 CoLUM. L. REv. 1611, 164749 (1981) (discussing the ambiguity of legitimacy).

5. Typical of the current rash of books on Japanese corporations are E. VoGEL, JAPAN AS Number ONE: LesSONS For AMERICA (1980); W. OUCHI, ThEORY Z: HOW AMERICAN BusINesS Can Meet the Japanese Challenge (1981). 
corporation in the long run, will be treated here as a manifestation of corporate ethical behavior. ${ }^{6}$ The category does not include those corporate actions that, though claimed to be altruistic, are in fact motivated by a desire to benefit the corporation. It does, however, include behavior that, though not motivated by a desire to benefit the corporation, inay in fact do so.

The American Law Institute explored the legal limits on business ethics in a recently released tentative draft entitled Principles of Corporate Governance and Structure: Restatement and Recommendations. ${ }^{7}$ A Restatement of corporation law has been on the ALI's agenda since its inception but, because of a lack of funding, earlier attempts floundered. ${ }^{8}$ The current project reflects the scholarly dissatisfaction with the existing law $^{9}$ by incorporating both a restateinent and recoininendations. It outlines what "corporate law should provide" rather than simply restating what it does provide. ${ }^{10}$ While this approach will probably cause the Statement $t^{11}$ to carry less weight than the other Restatements, it will nevertheless be an important guide for courts as well as for corporate officials.

Section 2.01 of the Stateinent discusses the object of the business corporation and attempts to balance the corporation's duty to its shareholders with its duty to society. ${ }^{12}$ Section 2.01 (b) provides that, although the object of the business corporation is to maximize long-term profits, the corporation may make decisions based on ethical considera-

6. This also assumes that the behavior is legally free from conflicts of interest.

7. Principles of Corporate Governance and Structure: Restatement and RecOMMENDATIONS (Tent. Draft No. 1, 1982) [hereinafter cited as STATEMENT].

8. Wechsler, Foreword to $i d$. at vii.

9. See, e.g., Werner, supra note 4, at 1612; Cary \& Goldschmid, Foreword to the Corporate Social Responsibility Symposium: Reflections on Directions, 30 HASTiNGS L.J. 1247 (1979); Cary, Federalism and Corporate Law: Reflections Upon Delaware, 83 YALE L.J. 663 (1974); H. MANNE $\&$ H. Wallich, The Modern Corporation and Social Responsibility (1972).

10. Wechsler, supra note 8, at ix.

11. Statemeut is the term used in the tentative draft to describe the ALI Restatement and Recommendations on Corporate Governance. Therefore, in this Comment, the project will be referred to as the Statement.

12.

$\S 2.01$. The Objective and Conduct of the Bnsiness Corporation

Corporate law should provide that the objective of the business corporation is to couduct business activities with a view to corporate profit and shareholder gain, except that, even if corporate profit and shareholder gain are not thereby enhanced, the corporation, in the conduct of its bnsiness by law,

(a) is obliged, to the same extent as a natural person, to act within the boundaries set

(b) Inay properly take into account ethical principles that are generally recognized as relevant to the conduct of business, and

(c) may devote resources, within reasonable hmits, to public welfare, humanitarian, educational, and philanthropic purposes.

STATEMENT, supra note $7, \S 2.01$. 
tions regardless of their effect on longrun profits. ${ }^{13}$

This Comment will argue that Section 2.01(b) should not be adopted. ${ }^{14}$ Part I outlines the current legal limits on corporate ethical activities. Part II describes the Statement's proposal and discusses the respects in which it departs from current law. Part III argues that: almost all of the ethical behavior validated under section 2.01(b) is already permitted under current legal standards; any remamimg conduct covered by section 2.01(b) should not be allowed; and, to the extent section 2.01(b) will influence corporate officials' exercise of discretion, it creates the risk that they will allocate resources incorrectly. Part IV concludes that longrun profit maximization, properly viewed, is the preferred standard by whicls to evaluate the ethical conduct of corporate officials.

\section{I \\ BACKGROUND LAW}

Historically, there have been two legal constraints on corporate officials' ability to act according to ethical principles: the duty of directors to act solely for the benefit of the corporation; and the ultra vires doctrine of restricted purposes and powers of the corporation. ${ }^{15}$ Today neither of these is a serious limitation on corporate ethical behavior. The wide deference which courts afford to corporate officials' decisions under the business judgment rule makes it difficult to challenge ethical behavior under either theory.

\section{A. Duty to the Corporation}

The first way to control corporate activity is to limit the power of corporate officials. ${ }^{16}$ The usual statutory formulation requires a director to manage corporate resources " $\mathrm{m}$ a manner he reasonably believes to be in the best interests of the corporation."17 The widely used Corporate Director's Guidebook explains this requirement as a "stewardship

\footnotetext{
13. Id.

14. Responding to even this single subsection in this format requires oversimplifying some and only referring to other coinplex and well-developed argunents im this area.

15. Note, Corporate Aliruism: A Rational Approach, 59 Gro. L.J. 117, 124-40 (1970).

16. This Comment recognizes, as does the Statement, that the senior officers must "manage" the corporation. STATEMENT, supra note $7, \S \S 3.01,3.02$. Directors and managers are therefore lumped together and referred to throughout this Comment as "corporate officials." Normally, the emphasis will be on the senior executives. Though the STATEMENT extends management duties to the officers, id. $\S 3.01$ comment $c$, the current law places these duties only on those officers who are also on the board, see, e.g., MODEL Business CORP. ACT ANN. 2D \& 35, i 2, at 256 (Supp. 1977). Therefore, when this Comment discusses the current law, "corporate officials" will be used in this narrower sense.

17. MODEL Business CoRP. ACT $\$ 35$ (1977). For an extended discussion of the business judgement rule in the various states, sce STATEMENT, supra note 7, pt. IV.
} 
for the owners of the enterprise, whose interests are interchangeably merged with the interests of the corporate entity." 18 Since the interests of the corporation and its shareholders are measured by corporate returns, the overriding duty of a corporate official is to maximize the corporation's longrun profits.

An official's "stewardship" is composed of two primary duties. 19 First is the duty of care. ${ }^{20}$ This duty mandates attention to corporate affairs as measured by the deferential business judgment standard. Second is the duty of loyalty. ${ }^{21}$ It disapproves conflicts of interest and imposes a standard of intrinsic fairness.

In a waste action, which alleges a violation of the duty of care, the business judgment rule affords wide deference to corporate officials' decisions. Under this rule, courts will not second-guess the business judgment of corporate officials. ${ }^{22}$ This judicial deference undercuts shareholder efforts to restraim corporate behavior motivated by ethics.

Many take the view that whatever is good for society must be good for the corporation in the long run. ${ }^{23}$ Given this perception, it becomes nearly impossible to prove that corporate behavior arguably motivated by ethical considerations is not in the best interest of the corporation. As long as corporate actions are even remotely related to longrun corporate benefit, and there is no taint of self-dealing or conflict of interest, officials' actions are virtually unreviewable. ${ }^{24}$ Where conflicts of imterest do exist, shareholders may challenge corporate officials' decisions as a violation of their duty of loyalty. Because the business judgment rule affords corporate officials such wide discretion, most shareholders challenge corporate behavior on theories of self-dealing or conflict of interest. ${ }^{25}$ In conflict of interest situations, corporate offi-

18. Corporate Director's Guidebook, 33 Bus. LAw. 1595, 1601 (1978).

19. Id at 1599 .

20. Id at 1600-04. Waste actions often arise in the context of inanageinent's power to resist hostile takeover bids. These cases usually reiterate the duty of inanagement to operate efficiently and maximize return to the shareholders. See Easterbrook \& Fischel, The Proper Role of a Target's Management in Responding to a Tender Offer, 94 HARv. L. Rev. 1161, 1190-91 (1981). However, $\$ 2.01$ (b) does not apply to takeover situations. STATEMENT, supra note 7, \$ 2.01 comment g.

21. Corporate Director's Guidebook, supra note 18, at 1599-600.

22. Kelly v. Bell, 254 A.2d 62, 75 (Del. Ch. 1969); W. CARY \& M. EISENBERG, CorPoraTIONS: CASEs AND MATERIALS 552-53 (5th ed. 1981); Johnson \& Osborne, The Role of the Business Judgment Rule in a Litigious Society, 15 VAL. U.L. REV. 49, 54 (1980).

23. See, e.g., A.P. Smith Mfg. Co. v. Barlow, 13 N.J. 145, 161, 98 A.2d 581, 590, cert. denied, 346 U.S. 861 (1953); Rostow, To Whom and for What Ends Is Corporate Management Responsible, in The Corporation IN MOdern Society 46, 64 (E. Mason ed. 1959).

24. See, e.g., Bishop, Sitting Ducks and Decoy Ducks: New Trends in the Indemnification of Corporate Directors and Officers, 77 YALE L.J. 1078, 1099-100 (1968); STATEMENT, supra note 7, pt. IV introductory note a, at 127-28; Note, supra note 15, at 131. This Comment will use the term "arguably profit inaximizing" to describe behavior that can pass inuster under this standard.

25. Bishop, supra note 24 . 
cials must prove the imtrinsic fairness of the transaction, absent proper shareholder approval. ${ }^{26}$ It is nearly impossible to find any cases holding a corporate official liable for waste where there was not at least a flavor of conflict of imterest. ${ }^{27}$

\section{B. Ultra Vires}

In the past, a second restraint on the behavior of corporate officials was an ultra vires action. ${ }^{28}$ This type of action was used to block corporate conduct that was beyond its authorized powers. ${ }^{29}$ Although this doctrine was historically important, today it is virtually dead..$^{30}$

Originally, the government granted corporations a limited franchise with specific purposes and powers. ${ }^{31}$ In addition to defining the scope of the franchise, the purposes and powers restrictions on corporate activity protected shareholder expectations about the type of busmess in which their money was invested..$^{32}$ A payment made without consideration and for ethical reasons might be ultra vires because the corporation was organized for profit, not for charity.

The decline of the doctrine of ultra vires began with the enactment of general imcorporation statutes. Beginning in 1837, states enacted these laws as a reaction against the special and monopolistic nature of corporate status. ${ }^{33}$ These statutes allowed corporations to perform any

26. Pepper v. Litton, 308 U.S. 295, 306-07 (1939); Perlman v. Feldmann, 219 F.2d 173, 177 (2d Cir. 1955); Chasin v. Gluck, 282 A.2d 188 (Del. Ch. 1971); Guth v. Loft, Inc., 23 Del. Ch. 255, 275, 5 A.2d 503, 512 (Sup. Ct. 1939); CAl. Corp. Code $\$ 310$ (West 1977); Del. Code ANN. tit. 8, $\S 144$ (1974); MODEL BusINess CoRP. ACT $\S 41$ (1979); Kaplan, Confict of Interests . . . Corporate Directors, 50 ILL. B.J. 1072, 1073 (1962); Wemrib, The Fiduciary Obligation, 25 ToRoNTo L.J. 1,18 (1975).

27. See, eg., Bishop, supra note 24. This Comment uses ethical behavior to mean behavior that can pass conflict of interest scrutiny.

28. See, e.g., Brinson Ry. Co. v. Exchange Bank, 16 Ga. App. 425, 85 S.E. 634 (1915); Worthington v. Worthington, 100 A.D. 332, 91 N.Y.S. 443 (1905).

29. W. CARY \& M. EISENBerg, supra note 22, at 39.

30. Theodora Holding Corp. v. Henderson, 257 A.2d 398 (Del. Ch. 1969); A.P. Smith Mfg. Co. v. Barlow, 13 N.J. 145, 98 A.2d 581, cert. denied, 346 U.S. 861 (1953); Union Pac. R.R. Co. v. Trustees, Inc., 8 Utah 2d 101, 329 P.2d 398 (1958). See generally R. Jennings \& R. BuXBaum, Corporations: CaSes and Materials 116-19, 131-35 (1979).

31. Louis K. Liggett Co. v. Lee, 288 U.S. 517, 554-56 (1933) (Brandeis, J. dissenting) (lists a number of the early statutory limits). $C f$. Werner, supra note 4, at 1621-27 (challenging Brandeis' view of history).

32. A. Berle \& G. Means, The Modern Corporation and Private Property 122 (rev. ed. 1967); A. Berle \& W. WARren, Business Organizations: Corporations 45.48 (1948); $c f$. E. DodD, AMERICAN BUSINESS CORPORATIONS UNTIL 1860, at 188-90 (1954) (arguing that these statutes were not strictly enforced); Werner, supra note 4, at 1623-27 (challenging this view of history).

33. The change began when Connecticut passed a statute allowing general incorporation "for any lawful purpose." By 1900, most states had similar statutes. A. BERLE \& G. MEANS, supra note 32 , at $126-28$. 
lawful business functions, ${ }^{34}$ and granted thein all the powers necessary to perform these general functions. ${ }^{35}$ With such an expansion of permissible corporate purposes and powers, it becanne extremely difficult for shareholders to prove that corporate behavior exceeded the scope of its franchise. ${ }^{36}$ In addition, strict statutory limits were placed on the scope of ultra vires actions. ${ }^{37}$

Despite the general purposes and powers clauses, some courts took a narrow view that prohibited charitable contributions. ${ }^{38}$ In response, nearly all states added a specific clause to their corporation statutes to allow corporations to make a reasonable annount of charitable contributions. ${ }^{39}$ These specific powers clauses are not intended to limit the corporation's general powers to pursue its profitunaking function. ${ }^{40}$ Rather, when combined with a broad view of corporate long-term profit and the busmess judgment rule's deference to the judgment of directors, ${ }^{41}$ they create a very broad range ${ }^{42}$ of corporate ethical activities allowable under the current law's overriding standard that corporate activity be profit maximizing. ${ }^{43}$

34. For the modern equivalents, see, for example, CAL. CORP. CODE $\$ \$ 202(b), 207$ (West 1977); Del. Code ANN. tit. 8, § 151 (1974); N.Y. Bus. CoRp. LAw $§ 201$ (McKinney 1963 \& Supp. 1982); MODEL BusinesS CORP. ACT $§ 54$ (1979).

35. For example, CAL. CORP. CODE $\S 207$ (West 1977) provides that, subject to limits in the articles and in statutes, a corporation shall lave all the powers of a natural person im carrying out its business activities, including without limitation, the power to: do business in other states; hold or transfer property; make charitable contributions; make contracts; pay employees; participate in partnerships. See also DeL. CODE ANN. tit. 8, \$§ 121-122 (1974); MODEL BuSINESS CORP. ACT $\S 4$ (1977).

36. See, e.g., Kelly v. Bell, 254 A.2d 62 (Del. Ch. 1969); Alderman v. Alderman, 178 S.C. 9 , 42, 181 S.E. 897, 911 (1935). See also R. Jennings \& R. BuXBaum, supra note 30, at 118 ("Given a business object reasonably within a statement of purposes, any transaction reasonably imcidental to its achieveinent should be legitimate.").

37. See, e.g., CAL. Corp. Code $\S 208$ (a) (West 1977); Del. Code ANN. tit. 8, § 124 (1974); MODEL BUSINESS CORP. ACT $\$ 7$ (1977).

38. See, e.g., McCrory v. Chambers, 48 Ill. App. 445 (1892); Hanrahan v. Andersen, 108 Mont. 218, 90 P.2d 494 (1939); Moore v. Keystone Macaroni Mfg. Co., 370 Pa. 172, 87 A.2d 295 (1952).

39. Arizona and Idaho are the only states that do not have such statutes. Note, supra note 15, at 137 n.113. The MODEL BuSINESS CORP. ACT $\S 4(\mathrm{in})$ (1977) provides that "each corporation shall have power... [t]o make donations for the public welfare or for charitable, scientific or educational purposes."

40. It is important to note that these enumerated powers are neither exclusive nor exhaustive.

41. Note, supra note 24.

42. See infra text accompanying notes 58-74. There is a very strong presumption that small expenditures will help the corporation, but larger expenditures will be evaluated in terms of their benefit to the corporation.

43. This range of allowable behavior will be referred to as "arguably profit maximizing." This recognizes that only a tiny portion of corporate behavior will actually be profit maximizing in the long run. Arguably profit maximizing includes all behavior that, though possibly nonmaximizing in the long run, provides a successful defense against an action for waste or ultra vires. Conduct not covered by this definition will be referred to as "clearly nonmaximizing." 


\section{II}

\section{LaW on Ethical Behavior Proposed by THE}

\section{STATEMENT}

The ALI Statement recommends that the "objective of the business corporation is to conduct busmess activities with a view to corporate profit and shareholder gam." ${ }^{44}$ The Reporter describes this clause as "a broad injunction to maximize econounic returns." 45 The State1nent, therefore, ignores the statutory structure of general corporate purposes and powers as a limitation on corporate behavior, ${ }^{46}$ and focuses on a requireinent similar to the profit maximization standard developed in the suits brought against directors for waste. ${ }^{47}$

The Statement provides three exceptions to its business objective admonition. The exceptions permit conduct that does not enhance corporate returns. First, section 2.01 (a) requires that the corporation obey the law regardless of economic cost. ${ }^{48}$ This requirement creates an affirmative duty to disregard the economic objective. ${ }^{49}$ Second, section 2.01(b) permits the corporation to make decisions based on ethical principles generally recognized as relevant to the conduct of business even if this will not enhance profits. ${ }^{50}$ Third, section 2.01(c) allows the corporation to donate reasonable amounts of resources "to public welfare, humanitarian, educational, and philanthropic purposes." 1

These three provisions of section 2.01 "reflect a recognition that the busmess corporation is a social as well as an economic institution,

44. STATEMENT, supra note $7, \$ 2.01$.

45. Id. comment e. (The Reporter for this section was Melvin Eisenberg.)

46. See, e.g., CAL. CORP. CODE $\$ 202$ (b)(1)(i) (West Supp. 1983) ("purpose of the corporation is to engage in any lawful act or activity for which a corporation may be organized"); see also $i d$. $\$ 207$ (e) ("corporation shall have all of the powers of a natural person . . . including, without himitation, the power to [m]ake donations regardless of specific corporate benefit"); MODEL BUSINESS CORP. ACT \$§ 3-4 (1977).

47. Statement, supra note 7, $\$ 2.01$ reporter's note 1. See, e.g., Dodge v. Ford Motor Co., 204 Mich. 459, 507, 170 N.W. 668, 684 (1919).

48. StaTEMENT, supra note $7, \$ 2.01$ comment d.

49. Id. Section 2.01(b) would appear to allow a private action against corporate officials who cause the corporation to violate the law even if the behavior was profit maximizing.

50. STATEMENT, supra note $7, \S 2.01$ (b). There inay also be a reasonableness component to the $\S 2.01$ (b) calculus. Though spending reasonable amounts to cushion the transition of cmployees is allowed under the general clause, $\S 2.01(\mathrm{~b})$ or $\$ 2.01$ (c), a company may not contribute indefinitely to the operation of a business that is losing large amounts of money for the purpose of keeping persons employed. STATEMENT, supra note 7, \$2.01 comment h, illustrations 20-21. The implication is that it is ethical only to take "reasonable" care of employees. The reasonableness of the amount may be more important than the appropriateness of the ethical principle; corporations inay not go down with even the most ethical of ships. Id. $\$ 2.01$ reporter's note 3 . As a stop-gap measure, an explicit reasonableness requirement could be added to $\$ 2.01$ (b). However, reasonableness must be evaluated in some way different from the longrun profit maxinization approach or the phrase "even if corporate profit and shareholder gain are not thereby enhanced" is rendered meaningless.

51. Statement, supra note $7, \S 2.01$ (c). 
and accordingly that its pursuit of the econonic objective must be constrained by social imperatives and may be qualified by social needs." 52 It asserts, in the tradition of Professor Dodd, ${ }^{53}$ that single-minded maximization of longrun profits is not an adequate goal for the corporation.

While sections 2.01(a) and 2.01(c) arguably restate the current law, ${ }^{54}$ section 2.01(b) breaks from the current law by recognizing that corporate conduct may be determined by ethical principles - even if the behavior is clearly not maximizing. ${ }^{55}$ The significance of this change is most apparent for corporations that are going out of business. The current law allows dissolving corporations less freedom to be ethical than continuing corporations. Because of the uncertainty of the future, continuing corporations are given wide latitude to pursue ethical behavior that may benefit the corporation in the long run. When a corporation is dissolving its view must be to the short run and the benefits of its actions more direct. For example, a continuing corporation might perforn a contract that is unenforceable against it because the longrun goodwill engendered will exceed the immediate loss. ${ }^{56}$ Under current law, a dissolving corporation im the same situation would not be able to perform the contract. However, section 2.01(b) expands the ethical discretion of the officials of a dissolving corporation to equal that of their counterparts in a continuing corporation. ${ }^{57}$

\section{III}

ANALYSIS

Section 2.01(b) should not be adopted. First, since there will be very little change in the legally permissible range or level of corporate ethical behavior under section 2.01(b), it is umiecessary. Second, to the degree it does make a difference, the change will be for the worse for several reasons. Section 2.01(b) will allow corporate officials broad discretion when a corporation is going out of business, a time when their scope of authority should be narrowed. Also, adjudication of the

52. Id. \& 2.01 comment d.

53. Dodd, supra note 1. Recent studies have emplasized the history of public responsibility for those corporations "affected with the public interest" that predates Dodd. See, e.g., Levy, The Law of the Commonwealth and Chief Justice Shaw, in AMERICAN LAw AND tHe Constitutional ORDER 151 (L. Friedman \& H. Scheiber eds. 1978); McCurdy, Justice Field and the Jurisprudence of Government-Business Relations: Some Parameters of Laissez Faire Constitutionalism, 1863-1897, $61 \mathrm{~J}$. Am. HIst. 970 (1975). However, there is a difference between ordinary corporations and "public" corporations, as well as between the government's right to require social responsibility and the limits on a director's ability to take voluntary action.

54. See, e.g., Miller v. AT\&T, 507 F.2d 759 (3d Cir. 1974) (business judgment rule does not apply when there is illegality); STATEMENT, supra note 7, $\$ 2.01$ comment b.

55. STATEMENT, supra note $7, \S 2.01$ comment g.

56. Id. § 2.01(b) comment e, illustration 1 .

57. Id. $\$ 2.01(\mathrm{~b})$ comment $\mathrm{g}$, illustration 11 . 
2.01(b) defense will waste judicial resources. A final disadvantage is that section 2.01(b), by encouraging ethical behavior without regard to corporate profitability, inay lead to ineffective and nonrepresentative decisionmaking.

\section{A. Section 2.01(b) is Unnecessary}

The law provides few constraints on corporate officials' ethical actions. ${ }^{58}$ With or without section 2.01 (b), it is nearly impossible to challenge ethically inotivated corporate behavior as either waste or ultra vires. To prove waste in light of the business judginent rule, one element the plaintiff must show is that the director's conduct will not maximize profits in the long run. Given the uncertainty of the future and the difficulty of predicting longrun outcomes, it is hard to show that an activity will not meet the profit test. The courts defer to corporate decisions if it appears that the board acted with a good faith concern for the longrun condition of the corporation.

An example of judicial deference to corporate officials' ethically motivated behavior is Dodge v. Ford Motor Company. ${ }^{59}$ In Dodge, the shareholders sought to restrict corporate expansion and to force payment of larger dividends. Management argued that production expansion would benefit the public generally even though it might be a less profitable strategy than other alternatives. ${ }^{60}$ In spite of this, the court declined to imterfere in production decisions. Despite explicit language in the opinion to the contrary, ${ }^{61}$ the court's holding affirmed the fact that philanthropic and altruistic sentmients could be a major mfluence

58. In contrast, the market appears to be a significant constraint. To the extent that the market is the final determinant of corporate behavior, corporate officials will strive to maximize profits regardless of the legal standard imposed. Manne, supra note 3, at 535. One measure of the importance of the market in determining the extent of nonmaximizing ethical behavior is that corporate donations average only about $1 \%$ of corporate net income, and even less for larger corporations. K. Troy, ANNUAL SURVEY of CoRPorate CONTRIBUTIONS (1981); J. MORRIS \& A. Klepper, Corporate Philanthropic Public Service Activities (Conf. Bd. Rep. No. 688, 1976). Another indicator of the market's effectiveness is the surprisingly small number of cases in this area. There are only 30 cases dealing with charitable contributions between 1853 and 1953. Garret, Corporate Donations, 22 Bus. Law. 297, 300 (1967); Prunty, Love and the Business Corporation, 46 VA. L. REv. 467, 470 (1960). One reason for this paucity of cases may be the fact that in a widely held corporation most shareholders cannot be hurt enough by specific nonmaximizing behavior to justify a lawsuit, especially when the market provides the altcrnative of selling at a fair price. Nevertheless, the amount of corporate charitable activity appears to be increasing, Teltsch, supra note 2, and it must be presumed for the purposes of this discussion that market imefficiencies permit less than perfectly profit-maximizing conduct. See e.g., R. HEILBRONER \& L. THUROW, The ECONOMIC PROBLem 56-66 (6th ed. 1981).

59. 204 Mich. 459, 170 N.W. 668 (1919).

60. An alteruative explanation of Ford's conduct was that management sought to establish a monopoly position in automobiles by flooding the inarket with inexpensive models.

61. 204 Micli. at 507,170 N.W. at 684 . 
in corporate decisions. ${ }^{62}$

Other cases follow the Dodge pattern: the courts voice acceptance of the profit-naximizing mandate; but give great latitude to directors to consider what appear to be altruistic factors. ${ }^{63}$ In Shlensky v. Wrigley, ${ }^{64}$ a plaintiff-shareholder sought damages and an order to compel the directors to install lights at Wrigley Field so that night baseball games could be played. There was substantial evidence that night games would enhance profits. The plaintiff asserted that the defendant's reasons for not imstalling lights were a belief that baseball was a daytime sport and a fear that imstallation of the lights would cause deterioration of the surrounding neighborhood. The court refused to interfere with the corporation's decision. Rather than rely on the two social reasons cited above, the court rested its position on the longrun interest of the corporation. It held that the refusal to imstall hights might prevent deterioration of the neighborhood, and thereby encourage attendance and maintam the property value of the stadium. ${ }^{65}$

Ultra vires is virtually ineffectual as a bar to ethical behavior. ${ }^{66}$ The last vestige of the doctrine, which prohibited corporate gifts to individuals, has largely disappeared. ${ }^{67}$ Although payments to widows of corporate officers have in the past been challenged successfully as ultra vires, ${ }^{68}$ it is doubtful that such a result would occur today. First, courts and commentators have moved away from a notion that pension funding for past services is ultra vires. ${ }^{69}$ Courts uphold these gifts by finding a benefit, no matter how tenuous, to the corporation. ${ }^{70}$ Likewise,

62. Id. The court did, however, compel payment of a very substantial dividend. This would indirectly affect the production decisions.

63. See, e.g., Armstrong Cork Co. v. H.A. Meldrum Co., 285 F. 58 (W.D.N.Y. 1922); A.P. Smith Mfg. Co. v. Barlow, 13 N.J. 145, 98 A.2d 581 (1953) (allowing a donation to Princeton University); Aldennan v. Aldennan, 178 S.C. 9, 42, 181 S.E. 897, 911 (1935); Union Pac. R.R. Co. v. Trustees, Inc., 8 Utah 2d 101, 329 P.2d 398 (1958) (allowing a donation to a general foundation without statutory authorization).

64. 95 Ill. App. 2d 173, 237 N.E.2d 776 (1968).

65. Id. at 180, 237 N.E.2d at 780.

66. See supra text accompanying notes $28-43$.

67. W. CARY \& M. EISEnberg, supra note 22, at 45 .

68. See, e.g., Adams v. Smith, 275 Ala. 142, 153 So. 2d 221 (1963); Moore v. Keystone Macaroni Mfg. Co., 370 Pa. 172, 87 A.2d 295 (1952).

69. Fogelson v. American Woolen Co., 170 F.2d 660 (2d Cir. 1948). In Fogelson, the corporation created a pension plan and one of the ineasures of one's benefit was past service. Id. at 611 . Although the court did question the size of the president's benefits, it did not question the concept of determining benefits based on past services. Id. at 663 .

70. See, e.g., Osborne v. Locke Steel Chain Co., 153 Conn. 527, 218 A.2d 526 (1966). In Osborne, a retired executive sued to enforce a corporation's promise to pay him specified incone for the duration of his life. The court found that the executive's promise not to coinpete and to be available for consultation was sufficient consideration to make the contract enforceable. Id. at 529. The court reached this conclusion although it agreed that, at least in part, the agreement was motivated by a desire to coinpensate the executive for past services. Id. at 530 . 
some commentators, mcluding the ALI and this Comment, find these "gifts" to be consistent with the goal of long-range profit maximization. ${ }^{71}$ Second, legislatures have enacted statutes that have weakened ${ }^{72}$ or overruled cases that held pension plans ultra vires. ${ }^{73}$ With or without section 2.01(b), therefore, even the "giving" of pensions for past services is generally within the discretion of corporate officials.

\section{B. Disadvantages of Section 2.01(b)}

Besides being unnecessary, section 2.01(b) is also disadvantageous for several reasons.

\section{Expands Discretion of Officials of Dissolving Corporations}

To the degree that section 2.01(b) leads to outcomes different from those under a longrun profit maximization standard, such outcomes are undesirable. A goimg concern will perceive hittle difference between conduct permitted by section 2.01(b) and behavior allowed under the profit maximization standard. The one situation where section 2.01(b) leads to a different outcome is when a company is going out of business. ${ }^{74}$ In the context of corporate dissolution, section 2.01(b) may result in abuses of corporate discretion. To avoid this danger, the better solution is to expand the view of longrun profit maximization to allow ethical corporate behavior, rather than to establish the section 2.01(b) exception.

The traditional standard of profit maximization hinits the discretion of corporate officials im a dissolving business. A profit-maximizing analysis of a dissolving company begms with the recognition that the firm lacks longrun profits to maximize. Corporate officials, limited to the short run, encounter less uncertainty about the effect of their behav-

71. Statement, supra note 7, $\$ 2.01$ comment e, illustration 2; Moyer, Encouraging Corporate Social Responsibility, in COMMENTARIES ON CORPORATE STRUCtURE AND GovernanCE 281 (D. Schwartz ed. 1979) [hereinafter cited as CommENTARIES].

72. Alabama's corporation code was amended in 1980 to grant corporations the power to loan inoney to employees and to establish incentive plans for employees. ALA. CODE § 10-2A$20(15)(1980)$. In addition, since the statute granted general purposes and powers, the court might have held that there was a business purpose for the donation.

73. 15 PA. Cons. Stat. \& 316 (1967). Pennsylvania enacted this law after Moore v. Keystone Macarom Mfg. Co., 370 Pa. 172, 87 A.2d 295 (1952), specifically to allow pensions for past services. See also Wis. STAT. ANN. § 180.31 (West 1957) (allowing pensions for past services).

74. The Statement's only illustration of behavior not otherwise allowed under the current law is a dissolving corporation's performance on an unenforceable contract. STATEMENT, supra note $7, \$ 2.01$ comment $\mathrm{g}$, illustration 11 . This would not include the common situation in which a large corporation closes a single plant or bquidates a subsidiary, since the parent corporation would still have a longrun profit picture. If the corporation were continuing, the behavior allowed under $\$ 2.01$ (b) would also be allowed under the Statement's general profit maximizing clause. Given the very broad view of profit maximization taken by the Statement, it is only when a corporation dissolves that corporate officials would need to turn to $\S 2.01$ (b) to justify their behavior. 
ior on the corporation. As uncertainty diminishes, so does the need for wide-ranging corporate discretion. Although still entitled to a measure of deference by the business judginent rule, liquidating corporations' officials have narrowed discretion under a profit maximization standard.

Contrary to the traditional standard, section 2.01(b) allows a dissolving corporation to be ethical regardless of the effect on profit. ${ }^{75}$ It provides no limitation on the discretion of corporate officials in this situation. This is unwise for several reasons. First, when a corporation is about to dissolve due to profitability problems, corporate officials should not be allowed to use corporate resources to engage in ethical behavior that clearly will not maximize those dwindling funds. ${ }^{76}$ In this situation, even a limited notion of corporate altruism can be unfair to shareholders. In a bankruptcy proceeding their interests will be subordinated to those of the corporation's creditors. ${ }^{77}$ It is unfair to force them to endure corporate actions that will further diminish their investinent. ${ }^{78}$ Even though the corporation's conduct would be consistent with ethical principles generally considered relevant to doing business, ${ }^{79}$ it is doubtful that already disappointed shareholders would prefer corporate altruisin over protecting what remains of their investment. It would be better to retain the assets for distribution to the shareholders, who could, if they chose, use the resources for altruistic purposes.

Second, severe financial difficulties rob a corporation of a major

75. Statement, supra note $7, \S 2.01$ comments a \& d.

76. It can be argued that the discretion of officials should be restricted even when a healthy corporation dissolves. See e.g., Prunty, supra note 58, at 472 (citing Hutton v. West Cork Ry. Co., $23 \mathrm{Ch}$. D. 654 (1883) (a dissolving corporation)). When they invest, shareholders expect to defer to corporate officials' expert understanding of inarket signals so that the corporation inay function efficiently and inaximize shareholder returns. Since the officials of a dissolving corporation have no market signals to guide thein, shareholders should not be required to defer to their judgments.

77. S. NADLER \& M. NADLER, The LAW OF BANKRUPTCY $\$ 14$ (2d ed. 1972).

78. These problems are especially sharp in the case of sinaller corporations. While soine provisions of the Statenent apply only to large publicly held corporations, $\$ 2.01$ is not so limited. A possible method of avoiding this problem is a variation on creditor protections contained in distribution restrictions. For a discussion of distribution requirennents, see W. CARY \& M. EISENBERG, supra note 22, at 1335-443. For example, California allows distributions to shareholders only if, after the distribution, assets equal 1.25 times liabilities. CAL. CORP. CODE $\S 500$ (West Supp. 1983).

Since voluntary payments harm all classes of creditors and shareholders, some test of general corporate health could be required before allowing ethical nonmaximizing behavior. This would separate those healthy corporations that are being dissolved or merged from the cases where the directors are fleeing a sinking ship. With this protection the risk of questionable "ethical" contributions would be greatly reduced.

79. The Statement makes clear that only ethics generally considered relevant to the conduct of business, as opposed to a corporate official's own idiosyncratic ethics, can justify acting in a nonmaximizing way. STATEMENT, supra note $7, \S 2.01$ comment g. 
justification for allowing its officials to behave without reference to profit maximization. One of the basic arguments for requiring corporations to act for ethical purposes, regardless of the effect on profits, is that corporations control vast resources and should use them to help solve society's probleins. ${ }^{80}$ A corporation experiencing financial difficulties, however, has no such burden of wealth and power. When its survival hangs in the balance, a corporation has neither the time nor the resources to find effective solutions to social problems.

Third, when the corporation is experiencing financial difficulties, ethical justifications may be subject to abuse. Liquidating corporations are ripe with conflicts. Officers may be tempted to engage in self-serving behavior. ${ }^{81}$ For example, managers of a corporation soon to go bankrupt may choose to perform an unenforceable contract in the hope of finding future employment with the other party. It is clear that this behavior would be upheld under $2.01(\mathrm{~b}){ }^{82}$

\section{Wastes Judicial Resources}

Another objection to section 2.01(b) is that it may waste judicial resources. Section 2.01(b), as a defense to a claim of corporate abuse of discretion, ${ }^{83}$ requires the court to determine whether the corporate conduct was proper. The Statement outlines two aspects of this inquiry. The Statement suggests that proper ethics are those generally recognized as relevant to the conduct of business. ${ }^{84}$ Furthermore, it recognizes that this standard may vary depending on the busmess. ${ }^{85}$ Section 2.01 (b) therefore requires a two-stage proof process. First, the court must determine the business category in which the corporation belongs. ${ }^{86}$ Second, it must hear evidence and determine what ethical conduct is appropriate in the context of that business. It is wasteful to engage the court in this complex inquiry when, for going concerns, section 2.01(b) leads to an outcome identical to that under the profit maximization rule.

80. See Baumol, Business Responsibility and Economic Behavior, in MaNaging the SoCially Responsible Corporation 59, 59-60 (M. Anshen ed. 1974); Lufkin, Some Financial Implications of Corporate Social Responsibility, in MANAGING THE SOCLALLY Responsible CoRPORATION, supra, at 128, 130-31.

81. While such ethical behavior does not reach the conflict of interest stage, its self-aggrandizing flavor might lead courts to invalidate it under the busimess judgement standard.

82. STATEMENT, supra note 7, § 2.01 comment $\mathrm{g}$, illustration 11 .

83. Though the wide discretion afforded corporate officials uncler a requirement of profit maximization provides ample support for most corporate decisionmaking, $\S 2.01$ (b) is likely to be raised as an alternative defense.

84. See supra note 12.

85. STAtement, supra note $7, \S 2.01$ comment $g$.

86. As many antitrust cases show, finding and defining the relevant market can be a very complex and expensive process. See, e.g., Harris \& Jorde, Market Definition in the Merger Guidelines, 71 CALIF. L. Rev. 464 (1983). 


\section{Motivates Incorrect Ethical Behavior}

The final argument against section 2.01(b) is that it distorts the amount and type of ethical behavior undertaken by corporations. Section 2.01(b) will have an educational effect of encouraging greater corporate beneficence independent of effect on profit. First this will cause ethically motivated decisions to be made with less information and expertise. Second, this educational effect encourages corporate officers to allocate the company's resources based on their nonrepresentative personal value choices and ethical perceptions.

The law, as an educational tool, can alter behavior even when there is no danger of sanction. ${ }^{87}$ One purpose of section $2.01(\mathrm{~b})$ is to educate corporate officials and to change the way resources are allocated to nonmaximizing activities. The drafters structured section 2.01(b) to maximize this effect. Though the current law allows a wide range of ethical behavior, it still contains an overrriding duty of profit maximization. Section 2.01(b) constitutes an exception to this general duty. It imstead creates a moral duty of corporations to take ethical principles into account. ${ }^{88}$ Additionally, it explictly permits actions that will not enhance profits. For the first time there is legal authority to support a corporation's decision to trade profits for ethics. Section 2.01(b), as an express validation of directors' conduct whereby "corporate profit and shareholder gain are not . . . enhanced"89 may result in a greater amount of corporate ethical behavior. ${ }^{90}$ This change im corporate conduct, however, may have unexpected adverse results.

To educate corporate officials to be inore beneficent without providing a financial context for that generosity may waste society's resources. First, by reinoving the standard of profit, section 2.01(b) eliminates the corporation's most familiar evaluative tool. ${ }^{91}$ Profit provides the context im which corporate officers develop expertise in inobilizing resources in response to market pressures. The "bottoin line" provides an essential gauge with which to measure whether the corpo-

87. Gustafson \& Johnson, The Corporate Leader and the Ethical Resources of Religion: A Dialogue, in JUDEo-ChristiAN VISION, supra note 3, at 306, 322.

88. While it seems unlikely that adoption of $\$ 2.01$ will lead directly to an imposition of a duty to be ethical, the current grant of discretion would probably be an argument in the future for the imposition of a corresponding duty.

89. STATEMENT, supra note $7, \S 2.01$.

90. It must be made clear that the greater educative effect of $\$ 2.01$ (b) does not result from the changed legal standard. The difference in legally permissible behavior under $\S 2.01(\mathrm{~b})$ and the requireinent of longrun profit maximization is very small. It might be argued that some of the same effects will occur under the current profit-maximizing standard. While this may be true, $\$ 2.01(b)$ will leave open the current possibilities for abuse and also encourage further ill effects.

91. Cutler, Economic Efficiency As the Focus of Structural Reform, in COMMENTARIES, supra note 71, at 346; Manne, supra note 3, at 538 . 
ration's mix of goods and services is optimal. ${ }^{92}$ Section $2.01(\mathrm{~b})$, by encouraging corporate altruism divorced from profit, deprives the corporation of essential feedback. Without any index of performance, the corporation may unintentionally misallocate its resources. ${ }^{93}$

Second, section 2.01 (b) may result in a less effective allocation of ethical dollars because it may encourage a shift of spending from local matters to national or global concerns. Thinking about ethics in the context of profits encourages activities that are more likely to benefit the corporation, and that are therefore closely connected with the corporation. The corporation's ethical resources will be better allocated close to home, where corporate officials can make more knowledgeable decisions as to the worthiness of the causes. The corporation has expertise and a long-term mterest in its locale, and can better monitor the situation to determine future spending. For example, directors know less about the impact of their efforts to stop the worldwide spread of commumism than about the impact of their donations on their home commumity. Section 2.01(b) may indirectly cause this type of shift in emphasis.

Third, officials may be teinpted to make critical decisions based on superficial ethical justifications rather than striving to find solutions that are profit maximizing as well as ethical. For example, corporate officials faced with an obsolete plant inay choose to avoid employee hardship by taking the obvious ethical step of operating the plant for an extra year while losing money. ${ }^{94}$ On the other hand, if forced to justify their ethical decisions on the basis of longrun profits, they may choose to retool the plant and thereby provide a better longrun solution, both for the corporation and for the employees.

Directors must determine both the overall amount of corporate resources to be devoted to nonmaximizing activities and the social purposes for which those funds will be expended. Without the objective standard of profit agamst which to assess the allocation of these resources, corporate officials are free to make these ethical choices based on their subjective perceptions and preferences. ${ }^{95}$ Although the State-

92. R. Heilbroner \& L. ThUROW, supra note 58 , at $372-77$.

93. See M. Friedman, Capitalism and Freedom 133-36 (1969).

94. STATEMENT, supra note $7, \S 2.01$ comment b, illustration 21 .

95. For evidence of the dangers from allowing corporate officials to justify their behavior with ethics, one need only read Medical Comm. for Human Rights v. SEC, 432 F.2d 659 (D.C. Cir. 1970), vacated as moot, 404 U.S. 403 (1972). In Medical Comm., the corporate officials attempted to justify the inanufacture of napalm, not because it was profit maximizing, but because it was ethical. Id. at 681. On the more general, philosophical problem of attributing ethical duties to a corporation, see R. McKean, Economics of Trust, Altruism, and Corporate Responsibility, in Altruism, Morality, AND Economic Theory 29, 37-42 (E. Phelps ed. 1975); Ladd, Morality and the Ideal of Rationality in Formal Organizations, 54 THE MoNIST 488 (1970); McClaughry, supra note 3 , at 6. 
ment limits the scope of ethical considerations permitted officials, ${ }^{96}$ there is no assurance that the corporation's decision will reflect either shareholders' or society's ethical preferences. ${ }^{97}$

Shareholders' preferences for ethical behavior are unlikely to be represented by corporate decisionmakers. Corporate democracy rarely extends to ensuring that the board of directors represents shareholders' ethical behefs. 98 Corporate elections are not designed to allow or to encourage shareholders to uncover candidates' values in order to ensure a board with whom they are ethically compatible. ${ }^{99}$ To do this would require a much more elaborate system of governance. Without major, and possibly harmful, ${ }^{100}$ reforin of the corporate governance system, ${ }^{101}$ it is unlikely that shareholders can ensure that corporate officials share their ethical outlook. ${ }^{102}$ The alternative, to require directors to factor shareholders' ethical assessments into particular decisions, is even more unworkable. No nuechanisn currently exists through which shareholders can effectively express their ethical preferences. Without this concrete guidance, to admonish directors to reflect shareholders' ethical preferences is hollow. ${ }^{103}$

96. STATEMENT, supra note $7, \S 2.01$ comment $\mathrm{g}$.

97. Cf. Hanson, Corporate Decision-Making and the Public Interest, in Judeo-CHRISTIAN Vision, supra note 3, at 330, 333 (arguing that this reliance is desirable).

98. The corporation inust be managed in accordance witl its articles and bylaws. In the Statement, the formulation is that "The board of directors of a publicly held corporation shall . . . monitor the conduct of the corporation's busmess to determine whether the corporation's resources are being managed in a manner that is consistent with the principles of $\$ 2.01$, corporate plans and policies, and the standards of the corporation." STATEMENT, supra note $7, \S 3.02$. The officers are held to a similar standard. See id. $\$ 3.01$ comment c.

99. In the past, some courts ensured the congruence of values by requiring unanimous shareholder consent to ultra vires type behavior. Putterman v. Daveles, 36 Del. Ch. 508, 515, 134 A.2d 480, 484 (1957); MacQueen v. Dollar Sav. Bank Co., 133 Ohio St. 579, 581, 15 N.E.2d 529, 531 (1938); Stoney Brook Lumber Co. v. Blackman, 286 Pa. 305, 309, 133 A. 556, 557 (1926).

100. See Sommer, Should Corporation Laws Restrain Antisocial and Illegal Conduct?, in CoMMENTARIES, supra note 71, at 255, 259; Novak, Can a Christian Work for a Corporation? The Theology of the Corporation, in JuDEo-Christian Vision, supra note 3, at 170, 192.

101. See Solomon, Restructuring the Corporate Board of Directors: Fond Hope-Faint Promise?, 76 Mrch. L. REv, 581 (1979).

102. Tabor, Let Corporate Law Stick to Its Last, in CoMmenTARIES, supra note 71, at 270, 271.

103. A modern approach to encouraging corporate directors to represent stockholder values is to allow directors to consider only those ethical principles contained in the articles or bylaws. This provides concrete standards for both courts and directors. In addition, shareholders would be on notice of the director's rights. Under this approach, concrete codes of ethics would evolve through business practice rather than through the vague and occasional formulations of the judicial process. This approach will also allow for the special businesses envisioned by the Statement to be clearly identified as such.

Though many of the same results could be achieved simply with a disclosure requirement, determiming which expenditures were "significant" and "nonmaximizing" enough to require disclosure would be difficult, and might lead to liability for nondisclosure in cases that would be allowed under present law. It is also easy to imagine a chilling effect on ethical contributions if they had to be disclosed in terms of, "This year the current corporate officials failed to maximize 
The argument against encouraging corporate officials to make ethical decisions without reference to longrun profits of the corporation is even stronger if one believes that corporate officials should represent society's ethical preferences. ${ }^{104}$ Society at large has no voice at all in the selection of corporate officials. It is unreasonable to expect the ethics of affiuent, well-educated meinbers of corporate boards to mirror the diverse ethics of our pluralistic society. ${ }^{105}$

\section{IV}

\section{The Correct View of Longrun Profit Maximization}

Longrun profit inaximization is a better standard than section 2.01(b) by which to judge the ethical conduct of corporate officials. The current law, which requires directors to act for the corporate benefit, provides sufficient latitude for ethical corporate behavior. The death of ultra vires and the wide scope of corporate decisionmaking allowed under the business judgement rule afford corporate officials broad discretion in acting according to ethical principles.

The extent of corporate discretion under traditional doctrines depends upon the time frame applied. A long-ternn perspective will allow inost ethical decisions to be validated. First, an extended time horizon increases the uncertainty of predicting any adverse outcomes of ethical decisions. Second, inost ethical conduct may ultimately result in profits for a healthy enterprise. Einphasizing profit maximization therefore does not mean that corporations will be less ethical. ${ }^{106}$ Corporations employ and deal with individuals who live according to ethical principles. Corporate morale and goodwill is enhanced if a corporation recognizes and acts upon these social and ethical concerns. Given the impossibility of predicting long-range impacts and the longrun profitability of most decisions, it is extremely difficult to find that a director's behavior, albeit made with reference to ethical principles, is not profit naximizing.

Longrun profit maximization, as a maxim for judging corporate altruism, is preferable to section 2.01(b). First, the profit maximization doctrine provides corporations with sufficient freedom to comport their

profits by . . . " Nevertheless, one might argue that the fact that disclosure seems so burdensome indicates that shareholders have in fact not fully accepted the notion of the corporation as a social institution.

104. See, e.g., Galbraith, On the Economic Image of Corporate Enterprise, in CoRPORATE Power IN AMERICA (R. Nader \& M. Green eds. 1973).

105. Tabor, supra note 102. Perhaps a inore accurate index of society's preferences is consumer conduct, as reflected in longrun corporate profits. If society agrees with a company's ethical position, it will evidence that approval by purchasing its product.

106. In fact, corporations may be failing to maximize profits by ignoring ethical concerns. See, eg., Kane, Investments with a Social Conscience, S.F. Chron., Mar. 23, 1983, at FF1, col. 1. 
behavior with ethical principles. ${ }^{107}$ Second, section 2.01 (b) creates adverse outcomes in those situations where ethical behavior would not be condoned under profit maximization. ${ }^{108}$ Finally, the profit maximization doctrine requires directors to justify ethical behavior by showing that it will benefit the corporation. This requirement forces corporations to pursue altruistic goals close to their business, thus maximizing the infornation available to them and allowing them to exploit special expertise. ${ }^{109}$ By improving corporate decisionmaking, profit maximization ensures that ethical decisions will be efficient and will therefore generate the most benefit to society.

\section{CONCLUSION}

The ALI Statement on Corporate Governance's section 2.01(b) proposes that business corporations be allowed to engage im ethical activities that will clearly not benefit them. This proposal provides a significant exception to the traditional overriding goal of the corporation, and duty of corporate officials, to maximize longrun profits. This Comment has argued that this overall goal should not be undercut by the adoption of section 2.01(b).

Section 2.01(b) appears to extend unjustifiably the discretion of corporate officials of dissolving corporations. In all other cases, section 2.01(b) is unnecessary and will result only in a waste of judicial resources. Finally, the indirect effect of this change may be to encourage less effective ethical decisions. It shifts the emphasis from profitability, an area of corporate expertise, to the corporate officials' personal ethical perceptions. Section 2.01(b) should therefore not be adopted.

M.J. Pritchett III*

107. See supra text accompanying notes 58-73.

108. See supra text accompanying notes 74-86.

109. See supra text accompanying notes 94-95.

* B.A. 1980, Brigham Young University; third-year student, Boalt Hall School of Law, University of California, Berkeley. 